慶應義塾大学学術情報リポジトリ

Keio Associated Repository of Academic resouces

\begin{tabular}{|c|l|}
\hline Title & New crystalline complexes composed of a fatty acid and nicotinamide \\
\hline Sub Title & \\
\hline Author & $\begin{array}{l}\text { 横山, 祥子(Yokoyama, Shoko) } \\
\text { 上田, 文雄(Ueda, Fumio) } \\
\text { 藤江, 忠雄(Fujie, Tadao) }\end{array}$ \\
\hline Publisher & 共立薬科大学 \\
\hline Publication year & 1992 \\
\hline Jtitle & $\begin{array}{l}\text { 共立薬科大学研究年報 (The annual report of the Kyoritsu College of } \\
\text { Pharmacy). No.37 (1992.) ,p.80-80 }\end{array}$ \\
\hline JaLC DOI & \\
\hline Abstract & \\
\hline Notes & 抄録 \\
\hline Genre & Technical Report \\
\hline URL & https://koara.lib.keio.ac.jp/xoonips/modules/xoonips/detail.php?koara_id=AN00062898-0000003 \\
& $7-0080$ \\
\hline
\end{tabular}

慶應義塾大学学術情報リポジトリ(KOARA)に掲載されているコンテンツの著作権は、それぞれの著作者、学会または出版社/発行者に帰属し、その権利は著作権法によって 保護されています。引用にあたっては、著作権法を遵守してご利用ください。

The copyrights of content available on the KeiO Associated Repository of Academic resources (KOARA) belong to the respective authors, academic societies, or publishers/issuers, and these rights are protected by the Japanese Copyright Act. When quoting the content, please follow the Japanese copyright act. 
No. 37 (1992)

\title{
New Crystalline Complexes Composed of a Fatty Acid and Nicotinamide*
}

\author{
Shoko Yokoyama, Fumio Ueda ${ }^{* *}$, and Tadao FujIE \\ 横山祥子, 上田文雄 ${ }^{* *}$, 藤江忠雄
}

New crystalline complexes composed of a fatty acid (FA) and nicotinamide (NAA) at a molar ratio of $6: 5,(\mathrm{FA})_{6}(\mathrm{NAA})_{5}$, have been isolated. The melting points of $(\mathrm{FA})_{6}(\mathrm{NAA})_{5}$ were higher than those of the corresponding equimolar complexes, $(\mathrm{FA})_{6}(\mathrm{NAA})_{6}$.

* 本報告は Bull. Chem. Soc.Jpn., 64（10), 3168一-3170（1991）に発表.

** 河合製薬株式会社研究所 